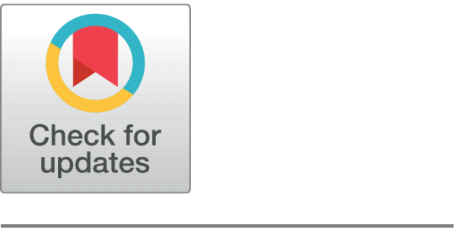

open ACCESS

Received: 18-01-2020

Accepted: $24-01-2020$

Published: $30-01-2020$

Editor: Dr. D. R. Galfat

Citation: Patkar D, Yadav R, Gaur S (2020) A study to analyse changes in serum electrolytes in heterotrophic ossification following traumatic brain injury. International Journal of Orthopaedics Traumatology \& Surgical Sciences 6(1): 1-4. https://do i.org/10.47618/IJOTSS/v6i1.1

* Corresponding author.

rajayadavbd7892@gmail.com

Funding: None

Competing Interests: None

Copyright: (c) 2020 Patkar et al. This is an open access article distributed under the terms of the Creative Commons Attribution License, which permits unrestricted use, distribution, and reproduction in any medium, provided the original author and source are credited.

Published By Society of Orthopaedics, Surgical and Dental Sciences

ISSN

Print: 2455-0809

Electronic: 2454-4167

\title{
A study to analyse changes in serum electrolytes in heterotrophic ossification following traumatic brain injury
}

\author{
Devendra Patkar ${ }^{1}$, Raja Yadav ${ }^{1 *}$, Sanjiv Gaur ${ }^{2}$ \\ 1 Resident, Gandhi medical college Bhopal \\ 2 Professor and head of department orthopaedics, GMC Bhopal
}

\begin{abstract}
Heterotopic ossification ( $\mathrm{HO}$ ), also known as heterotopic bone formation, is the presence of the lamellar bone within soft tissues where the bone physiologically does not exist. Aims and Objectives: To analyse changes in seum electrolytes in heterotrophic ossification following traumatic brain inury. Material and Methods: Brain injury patients were included in tertiary care centre and examined for heterotrophic ossification. Result: Significant changes were observed in serum calcium levels.
\end{abstract}

Keywords: Traumatic brain injury; heterotrophic ossification; serum electrolytes

\section{Introduction}

Heterotopic ossification (HO), also known as heterotopic bone formation, is the presence of the lamellar bone within soft tissues where the bone physiologically does not exist. It is a complication of numerous types of trauma, including hip arthroplasty, electrical injury, neurological injuries and thermal. Reidel first described HO in 1883, and in 1918 Dejerne and Ceillier reported that HO frequently occurred among soldiers who had experienced spinal cord trauma as combatants in World War I. (Dejerne A et al, 1918) ${ }^{(1)}$

Three types of $\mathrm{HO}$ are distinguished: myositis ossificans circumscripta, myositis ossificans progressiva and localized traumatic myositis ossificans. Myositis ossificans refers rather to a condition in which ectopic bone is formed within muscles and other soft tissues. Ectopic calcification is a mineralization of softtissue structures, which usually follows chemical or physical trauma, as in tendinitis calcarea. Histologically, a calcium deposit rather than new bone would be formed. (Mollan RAB, 1979) ${ }^{(2)}$

$\mathrm{HO}$ is a common complication of traumatic spinal cord injuries with a prevalence ranging from 5 to $50 \%$, depending upon the studies design and the diagnosis method. The progression of $\mathrm{HO}$ may lead to decreases in the range of motion and ankylosis and has a negative impact on the rehabilitation processes. The most affected joints are the hips (60\%-70\%) and knees (20\%-30\%). (Hernandez AM et al, 1978) ${ }^{(3)}$

The clinical signs and symptoms of HO may include pain, stiffness, loss of joint range of motion (ROM), swelling or warmth of joint area, fever, increased 
spasticity, joint pain, muscle pain, and autonomic dysreflexia and functional impairments. Whereas many studies have investigated $\mathrm{HO}$ after hip trauma or replacement surgery. It may appear as early as $3 \mathrm{wk}$ or as late as $12 \mathrm{wk}$ after the musculoskeletal trauma, spinal cord injury, or other precipitating event. (B.E. Ellerin et al, 1999) ${ }^{(4)}$

Risk factors including concomitant polytrauma, infection, and blast injuries, male gender, presence of prior $\mathrm{HO}$, previous hip surgery and lateral and anterolateral hip approaches. Some pathologies have been associated with a higher rate of $\mathrm{HO}$, such as ankylosing spondylitis, hypertrophic osteoarthritis, diffuse idiopathic skeletal hyperostosis, Paget disease, Parkinson's disease and rheumatoid arthritis. The incidence of HO in hip surgery can be vastly different in different ethnic groups. Additionally, close to $20 \%$ of patients with spinal cord injuries and traumatic brain injuries develop HO. (Bossche LV et al, 2005) ${ }^{(5)}$

Complications of $\mathrm{HO}$ inc lude peripheral nerve entrapment, pressure ulcers, and functional impairment if joint ankylosis develops. Therefore, prophylaxis or early treatment of $\mathrm{HO}$ is extremely important. Once the diagnosis of early $\mathrm{HO}$ is confirmed, passive range-of-motion exercises to maintain joint mobility are recommended. More aggressive joint manipulation has been suggested, although the trauma resulting from this approach carries the risk of inciting further $\mathrm{HO}$. (Stover SL et al, 1975) ${ }^{(6)}$

Biphosphonates and nonsteroidal antiinflammatory drugs (such as indomethacin and ibuprofen) have been used for the prophylaxis or treatment of HO. However, there is no consensus on which drug should be used and when treatment should begin. Radiation therapy has also successfully been used to prevent or treat HO. (Neal BC et al, 2000) ${ }^{(7)}$

The currently available treatments are still highly controversial. As primary prevention, risk factors such as pressure ulcers, deep venous thrombosis and limb contractures should be avoided.

Rehabilitation can play an important role not only in the prevention of contractures but also in the maintenance of a good physical condition, obviating the need for additional treatment. Importantly, forcible ROM of joints can induce microtrauma and haemorrhages, which may increase $\mathrm{HO}$ formation. Recent studies have shown a favorable effect of active and passive exercising of joints within the pain-free range. (Van Kuijk AA et al, 2002)

The present study is an attempt to analyze the etiologic factors of heterotopic ossification.

\section{Aims and Objectives}

To analyse changes in seum electrolytes in heterotrophic ossification following traumatic brain inury.

\section{Materials and Methods}

\subsection{Inclusion criteria}

1. All patients admitted and attending OPD of tertiary care center in Bhopal, India

2. Patients giving written consent to be part of study

3. Patients without previous history of major surgery

4. Patients with head injury

\subsection{Exclusion criteria}

1. Patients not giving written consent to be part of study

2. Patients with previous history of major surgery

3. Patients without head injury

All patients were followed up, either as part of their inhospital stay or during their follow-up visits.

Detailed history was taken, through clinical examination done followed by biochemical investigations. Radiographs of affected extremity taken in two perpendicular views.
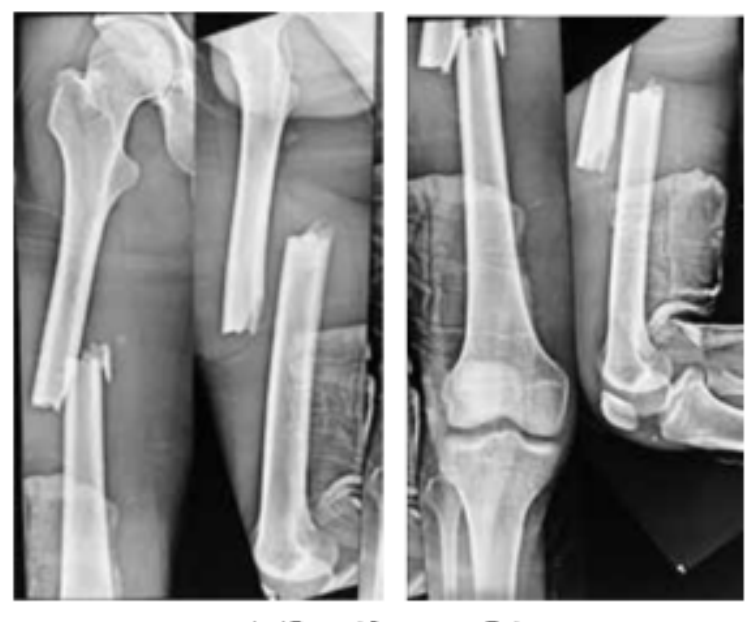

$x$-ray at the time of trauma

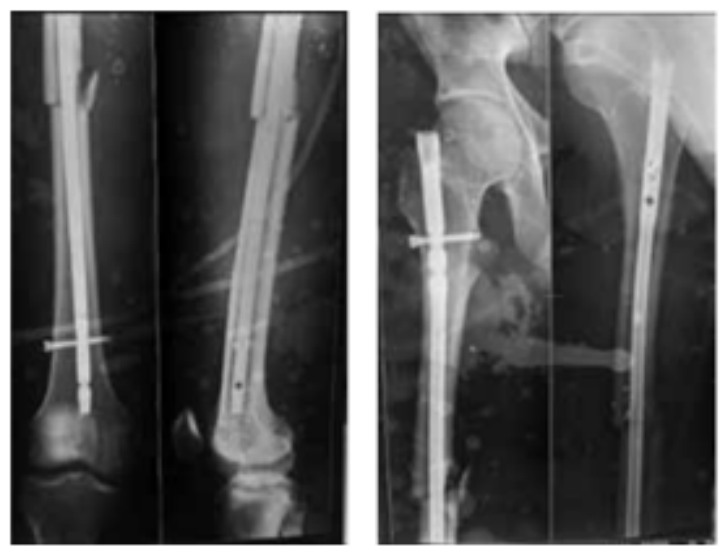

Immediate post-op x-ray 

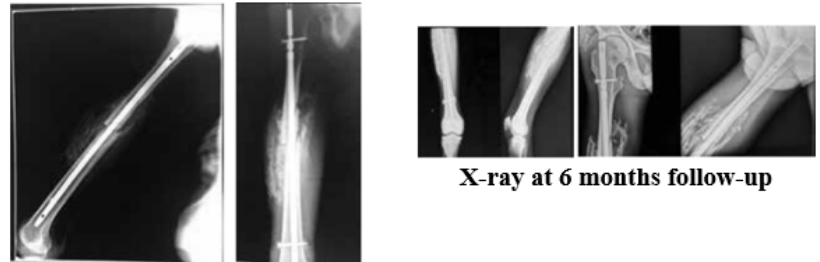

X-ray at 6 months follow-up

\section{Results}

\begin{tabular}{|c|c|c|c|c|}
\hline Parameters & $\begin{array}{c}\text { Follow Up } \\
\text { (months }\end{array}$ & Mean & $\begin{array}{c}\text { Std. } \\
\text { Deviation }\end{array}$ & P value \\
\hline \multirow{3}{*}{ S. Po4 } & 0 & 3.67 & 1.465 & \multirow{3}{*}{0.744} \\
\hline & 3 & 3.46 & .779 & \\
\hline & 6 & 3.67 & .868 & \\
\hline \multirow{3}{*}{ Calcium } & 0 & 7.83 & 1.494 & \multirow{3}{*}{0.004} \\
\hline & 3 & 7.71 & 1.756 & \\
\hline & 6 & 8.96 & .690 & \\
\hline \multirow{3}{*}{ Potassium } & 0 & 4.42 & 1.018 & \multirow{3}{*}{0.776} \\
\hline & 3 & 4.33 & .761 & \\
\hline & 6 & 4.50 & .590 & \\
\hline \multirow{3}{*}{ Sodium } & 0 & 138.29 & 4.448 & \multirow{3}{*}{0.306} \\
\hline & 3 & 134.54 & 21.950 & \\
\hline & 6 & 140.33 & 3.807 & \\
\hline \multirow{3}{*}{$\mathrm{HCO} 3$} & 0 & 23.42 & 2.185 & \multirow{3}{*}{0.510} \\
\hline & 3 & 23.04 & 1.654 & \\
\hline & 6 & 22.79 & 1.719 & \\
\hline
\end{tabular}
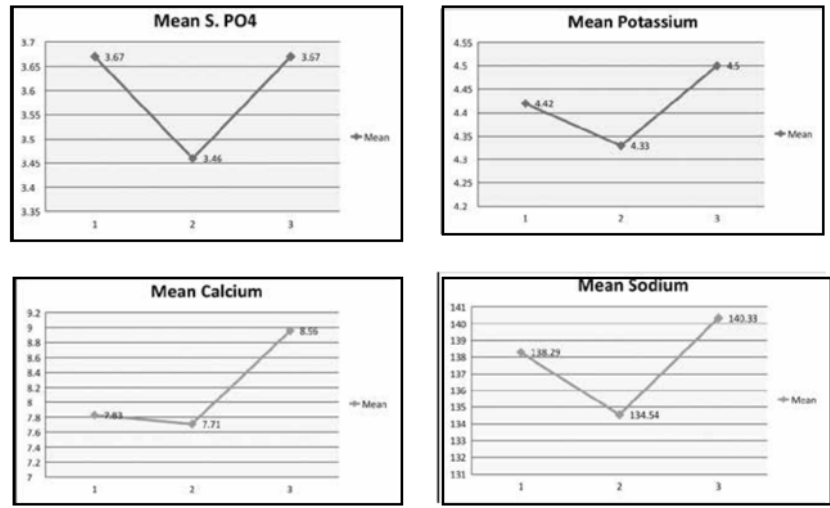

\section{Discussion}

Heterotopic ossification ( $\mathrm{HO}$ ) is a frequent complication in patients with a spinal cord injury (SCI), while the etiology of $\mathrm{HO}$ is unknown.

In present study, there was a significant change observed in terms of serum calcium which was significantly increased from 7.83 from baseline to 7.71 at 3 months to 8.96 at the end of 6 months of follow up $(\mathrm{p}=0.04)$. However other laboratory parameters like serum potassium, serum sodium, $\mathrm{HCO} 3$ and SPo4 were similar across all the follow up as compared to baseline values. Similar study by S W Kim et al study results showed that AP, P, and Ca by themselves were of little help in the diagnosis of HO. However, the combination of elevated AP and $\mathrm{P}$ was significant, especially if both were consistently elevated. 55 Similar study by Ryu S-R, et al reported serum calcium as $4.2 \mathrm{mEq} / \mathrm{L}$ (normative range, $4.25 .1 \mathrm{mEq} / \mathrm{L}$ ) and ionized calcium was $2.0 \mathrm{mEq} / \mathrm{L}$ (normative range, $2.02 .4 \mathrm{mEq} / \mathrm{L}$ ) in patients of HO.5

\section{Conclusion}

Present study, there was a significant change observed in terms of serum calcium which was significantly decreased from 7.83 from baseline to 7.71 at 3 months and thereafter to 8.96 at the end of 6 months of follow up ( $\mathrm{p}=0.04)$. However other laboratory parameters like serum potassium, serum sodium, HCO3 and SPo4 were similar across all the follow up as compared to baseline values.

\section{References}

1) Dejerne A, Ceillier A. Para-osteo-arthropathies des paraplegiques par lesion medullaire; etude cli-nique et radio graphique. Ann Med. 1918;5:497-497.

2) Mollan RA. Serum alkaline phosphatase in heterotopic para-articular ossification after total hip replacement. The Journal of Bone and Joint Surgery British volume. 1979;61-B(4):432-434. Available from: https: //dx.doi.org/10.1302/0301-620x.61b4.115891.

3) Hernandez AM, Forner JV, Fuente TDL, Gonzalez C, Miro R. The paraarticular ossifications in our paraplegics and tetraplegics: a survey of 704 4.Patients. Paraplegia. 1978;16:272-275. 
4) Ellerin BE, Helfet D, Parikh S, Hotchkiss RN, Levin N, Nisce L. Current therapy in the management of hetero topic os-sification of the elbow: a review with case studies. Am J Phys Med Rehabil. 1999;78:259-271.

5) Bossche LV, Vanderstraeten G. Heterotopic ossification: A review. Journal of Rehabilitation Medicine. 2005;37(3):129-136. Available from: https: //dx.doi.org/10.1080/16501970510027628.
6) Stover SL, Hataway CJ, Zeiger HE. Heterotopic ossification in spinal cordinjured patients. Arch Phys Med Rehabil. 1975;56:199-204.

7) Neal BC, Rodgers A, Clark T. A sys t ema t i c surve y of 13 randomized trials of non-steroidal anti-inflammatory drugs for the prevention of heterotopic bone formation after major hip surgery. Acta Orthop Scand. 2000;71:122-128. 